\title{
The ShORTCOMINGS OF Regulation Through LITIGATION IN BIOTECHNOLOGY
}

\author{
AMY WAITE ${ }^{*}$
}

\section{INTRODUCTION}

In September of 2017, Syngenta AG, a global agriscience company, agreed to pay U.S. farmers over one and a half billion dollars for disrupting U.S. corn exports to China. ${ }^{1}$ Importantly, before selling the product that caused the disruption, Syngenta received full regulatory approval for the product in the United States. ${ }^{2}$ Syngenta's settlement illustrates the business risk biotechnology developers incur as a result of misaligned international regulations for biotechnology and efforts to supplement the existing regulatory framework through litigation. ${ }^{3}$

Syngenta began marketing its biotech product, MIR162 corn, ${ }^{4}$ to U.S. farmers in 2011 following U.S. regulatory approval of the biotech corn seed in $2010{ }^{5}$ U.S. farmers planted the seed across the country, and after harvest, the corn containing MIR162 was eventually comingled with other U.S. corn to be exported to China. ${ }^{6}$ In 2013, China received corn containing the MIR162 trait, and China subsequently rejected the shipment along with all other future shipments of U.S. corn. ${ }^{7}$ China claimed to reject the corn because the Chinese Ministry of Agriculture had not yet approved MIR162. ${ }^{8}$ Following the loss of the Chinese export market, U.S. corn prices plummeted. ${ }^{9}$ In response, U.S. farmers brought a class action lawsuit against Syngenta for negligently marketing

* J.D., Indiana University Robert H. McKinney School of Law, 2019; B.S. Agricultural Sales and Marketing, Purdue University, 2016.

1. Sonja Begemann, Syngenta Settles MIR162 Case for $\$ 1.51$ Billion, AGWeB (Mar. 12, 2018, 5:02 PM), https://www.agweb.com/article/syngenta-settles-mir162-case-for-151-billion-naasonja-begemann [https://perma.cc/ZYW9-YCN6].

2. Thomas P. Redick et al., Litigation and Regulatory Challenges to Innovation in Biotech Crops, 20 Drake J. Agric. L. 71, 75 (2015).

3. See In re Syngenta AG MIR162 Corn Litig., 131 F. Supp. 3d 1177 (D. Kan. 2015).

4. MIR162 is a genetic modification designed to prevent insect damage to corn. Corn containing the MIR162 trait is marketed under the trade name Agrisure Viptera ${ }^{\circledR}$. Agrisure Vitpera, SYNGENTA, http://www.syngenta-us.com/agrisure/agrisure-viptera.aspx [https://perma.cc/C75TWZ38].

5. Margaret Cronin Fisk \& Tim Bross, Syngenta Loses $\$ 218$ Million Verdict in First GMO Trial Test, BloOMBerg (June 23, 2017, 12:21 PM), https://www.bloomberg.com/news/ articles/2017-06-23/syngenta-ordered-by-jury-to-pay-2 18 -million-to-kansas-farmers [https://perma.cc/8J86-ZVEN].

6. Id.

7. $I d$.

8. $I d$.

9. See In re Syngenta AG MIR162 Corn Litig., 131 F. Supp. 3d 1177 (D. Kan. 2015). 
MIR162 before obtaining its approval in the major export market ${ }^{10}$ of China. ${ }^{11}$

The Syngenta litigation is the first class action to allege negligence against a company for marketing a biotech product with full U.S. regulatory approval. ${ }^{12}$ But Syngenta is not alone in facing costly settlement payouts as a result of biotechnology regulations and export conflicts; ${ }^{13}$ at least four other global agriscience companies paid significant settlements for disrupting export markets. ${ }^{14}$ In 2014, Monsanto agreed to pay $\$ 2.4$ million to wheat farmers in Idaho, Oregon, and Washington to settle claims that genetic contamination of U.S. wheat disrupted export markets. ${ }^{15}$ Bayer CropScience paid more than $\$ 750$ million in settlements for the comingling of biotech rice, which resulted in trade disruption to the European Union. ${ }^{16}$ And in 2012, Aventis CropScience paid $\$ 110$ million for trade disruptions resulting from the comingling of its biotech corn. ${ }^{17}$ This biotechnology litigation represents a pattern of liability from the loss of export markets, which ultimately stems from piecemeal regulatory systems around the globe. ${ }^{18}$ Regulatory inconsistencies are a source of business risk for biotechnology companies and must be harmonized internationally to ensure innovation is not quashed by the threat of liability. ${ }^{19}$

Part I of this Note synopses the history and significance of Genetically Modified Organisms ("GMOs"), and Part II outlines how the United States and other countries regulate GMOs. Part III of this Note explores the concept of regulation through litigation and specifically addresses the rise of class action litigation as a means of supplementing a disjointed GMO regulatory system. Part IV of this Note argues that reliance on class action litigation as a means of GMO regulation has three fundamental flaws. First, class action litigation cannot remedy the asynchronous approvals that ultimately give rise to export disruptions on the world stage. Second, regulation through litigation generates incomplete regulations that have the potential to create great uncertainty in the regulated industry. Third, class actions disadvantage American farmers by limiting their access to technology and disadvantage American businesses by limiting potential return on investment for biotech products in the United States. Finally, Part V of this Note addresses a domestic supply chain solution and advocates for the harmonization of international regulatory systems as companies attempt to

10. "Major market approval" is the phrase used to describe the regulatory approval of a biotech product in a significant export market. See Know Before You Grow, NAT'L CORN GROWERS Ass'N, http://www.ncga.com/for-farmers/know-before-you-grow [https://perma.cc/ZRC5-ZAMT].

11. See Syngenta, 131 F. Supp. 3d 1177.

12. See generally Redick et al., supra note 2 .

13. Id.

14. Id.

15. Id. at 80 .

16. Id. at 82 .

17. Id. at 83-84.

18. See generally id.

19. See generally Plant Biotechnology Regulatory, CROPLIFE INT'L, https://croplife.org/ plant-biotechnology/regulatory-2 [https://perma.cc/4NAC-9R96]. 

THROUGH LITIGATION IN BIOTECHNOLOGY

manage risk while continuing to invest in biotechnology.

\section{THE HISTORY AND SIGNIFICANCE OF GMOS}

Humans relied on selective breeding to improve the genetics of plants and animals for thousands of years, but the advent of genetic engineering in 1973 revolutionized scientists' ability to alter an organism's genome. ${ }^{20}$ Genetic engineering is the process of taking a gene from one organism and adding it to another; this is the process used to create GMO crops. ${ }^{21}$ The United States approved the first genetically-engineered, insecticide-producing crop in $1995 .^{22}$ This marked the beginning of large-scale production of GMO crops in the United States. ${ }^{23}$ Although the United States was an early adopter of GMO technology, use of GMO crops quickly expanded. ${ }^{24}$ Now, more than seventy-five nations import, grow, and/or research GMOs. ${ }^{25}$

GMOs improve the sustainability of agriculture ${ }^{26}$ by benefitting people, planet, and profit - the three components of a sustainable industry's triple bottom line. ${ }^{27}$ Ten GMO crops are grown in the United States: corn, soybeans, cotton, potatoes, papaya, squash, canola, alfalfa, apples, and sugar beets. ${ }^{28}$ Some of these crops are modified to produce their own insecticide - thereby limiting the need to apply insecticide chemicals in the field. ${ }^{29}$ Other crops are modified to resist herbicides so farmers can control weeds and increase yields without disturbing the soil through cultivation. ${ }^{30}$ Insects and weeds are two of the greatest threats to crop yield, and addressing these threats through genetic modification allows

20. Gabriel Rangel, From Corgis to Corn: A Brief Look at the Ling History of GMO Technology, Harv. U. SCI. News Blog (Aug. 9, 2015), http://sitn.hms.harvard.edu/flash/2015/ from-corgis-to-corn-a-brief-look-at-the-long-history-of-gmo-technology [https://perma.cc/V57MJB4L].

21. Id.

22. $I d$.

23. See generally id.

24. GMOs Globally, GMO ANSWERS, https://gmoanswers.com/gmos-globally [https://perma.cc/9NXB-WXPH].

25. Id.

26. Eshna Gogia, GMOs: Road to Sustainable Agriculture, Medium (Oct. 14, 2017), https://medium.com/@eshna_gogia/gmos-road-to-sustainable-agriculture-880c1413ea8 [https://perma.cc/GHF2-7LDF].

27. Triple Bottom Line, ECONOMIST, https://www.economist.com/node/14301663 [https://perma.cc/D88V-4UC4].

28. Which Genetically Engineered Crop and Animals Are Approved in the US?, GENETIC LiterACY PROJECT: GMO FAQ, https://gmo.geneticliteracyproject.org/FAQ/which-geneticallyengineered-crops-are-approved-in-the-us [https://perma.cc/6A6U-WAJG].

29. Rangel, supra note 20.

30. See generally id. 
farmers to produce more per acre. ${ }^{31}$ In fact, the yield gains from GMOs are so significant that through the use of biotechnology, the world could use one-fifth less land to produce the same amount of food. ${ }^{32}$

But reduced insecticide use, reduced soil cultivation, and reduced need for tillable acreage are not the only benefits of GMO crops. ${ }^{33}$ Drought-tolerant GMO varieties also reduce agriculture's use of water, and bruising-and-browningresistant GMO varieties minimize waste and improve food quality. ${ }^{34}$ GMO crops reduce the environmental impact of food production, increase the global food supply, and improve access to affordable food. ${ }^{35}$

In a little more than forty years, GMOs have revolutionized the sustainability of food production. ${ }^{36}$ GMOs benefit people by improving food quality and access to food. ${ }^{37}$ GMOs benefit the planet by reducing food production's demand on natural resources, reducing insecticide use, and improving soil health. ${ }^{38}$ And finally, GMOs benefit farm profitability by reducing input costs and improving yields. ${ }^{39}$

\section{THE REGULATION OF GMOS}

Dozens of individual governments review and regulate GMOs around the world. ${ }^{40}$ Unfortunately, these regulations are far from harmonized and vary in approach. ${ }^{41}$ Even within the United States, biotech manufacturers must satisfy the regulatory requirements of three different agencies ${ }^{42}$ to bring a GMO product to market. ${ }^{43}$

\section{A. Domestic Regulation}

In the United States, the Coordinated Framework for Regulation of

31. Omri Ben-Shahar, The Environmentalist Case in Favor of GMO Food, ForBES (Feb. 26, 2018, 7:24 PM), https://www.forbes.com/sites/omribenshahar/2018/02/26/the-environmentalistcase-in-favor-of-gmo-food/\#63c7c9ce37de [https://perma.cc/8VZU-MUEV].

32. Id.

33. Gogia, supra note 26.

34. Id.

35. Id.

36. See generally Rangel, supra note 20.

37. Gogia, supra note 26.

38. Ben-Shahar, supra note 31.

39. See generally Gogia, supra note 26.

40. Global Approvals of GMO Crops, GMO ANSwERS, https://gmoanswers.com/globalapprovals-gmo-crops [https://perma.cc/TZP3-4USJ].

41. Plant Biotechnology Regulatory, supra note 19.

42. The three agencies are the United States Department of Agriculture, the Environmental Protection Agency, and the Food and Drug Administration.

43. See generally Coordinated Framework for Regulation of Biotechnology, 51 Fed. Reg. 23,302 (June 26, 1986). 

THROUGH LITIGATION IN BIOTECHNOLOGY

Biotechnology (“Coordinated Framework”) governs GMO regulations. ${ }^{44}$ In 1986, the Coordinated Framework became official U.S. policy. ${ }^{45}$ This Framework is a "risk-based system to ensure that new biotechnology products are safe for the environment and human and animal health." ${ }^{\prime 6}$ The Coordinated Framework allocates the responsibility of regulating biotechnology among three federal agencies: (1) the United States Department of Agriculture ("USDA"), (2) the Environmental Protection Agency ("EPA"), and (3) the Food and Drug Administration ("FDA"). ${ }^{47}$

Under the Coordinated Framework, the USDA's primary role is the regulation of noxious weeds and plant pests that pose a potential risk to the agriculture industry. ${ }^{48} \mathrm{New}$ biotech plant varieties are considered "plant pests. ${ }^{, 49}$ The authority for this regulation comes from the Plant Protection Act, ${ }^{50}$ and the Animal and Plant Health Inspection Service carries out USDA's regulatory responsibilities regarding plant biotechnology. ${ }^{51}$

The FDA's authority to regulate biotechnology is primarily derived from the Federal Food, Drug, and Cosmetic Act although no provision of the Act expressly covers GMO foods. ${ }^{52}$ Under this Act, the FDA ensures that adulterated products are not made commercially available for human consumption. ${ }^{53}$ The presence of a pesticide chemical residue produced by a GMO trait may render a product adulterated. ${ }^{54}$

The EPA regulates plants that are genetically modified to produce their own pesticide. ${ }^{55}$ A GMO variety that has been modified in this way is also known as a Plant Incorporated Protectant. ${ }^{56}$ Just as any other pesticide requires agency registration under the Federal Insecticide, Fungicide, and Rodenticide Act, ${ }^{57}$ Plant Incorporated Protectants must also receive registration prior to commercialization. ${ }^{58}$

44. Id.

45. Id.

46. Paul Goeringer, Adapting to the Changing World of Biotechnology: Syngenta AG MIR162 Corn Litigation as Regulation by Litigation, 4 TEX. A\&M L. REV. 373, 377 (2017) (internal quote omitted).

47. Coordinated Framework for Regulation of Biotechnology, 51 Fed. Reg. 23,302.

48. Maria R. Lee-Muramoto, Reforming the "Uncoordinated" Framework for Regulation of Biotechnology, 17 DRAKE J. AGRIC. L. 311, 317-18 (2012).

49. Id.

50. Id. at 318 .

51. Id.

52. Id. at 320 .

53. 21 U.S.C. $\S 342(2017)$.

54. Id.

55. Lee-Muramoto, supra note 48, at 322.

56. $I d$.

57. Goeringer, supra note 46 , at 378 .

58. Lee-Muramoto, supra note 48, at 322. 
Legal scholars and scientists criticize the Coordinated Framework as being antiquated, fragmented, and inefficient. ${ }^{59}$ For example, the Coordinated Framework focuses on the safety of the end product rather than the process by which the product was created ${ }^{60}$ Because of this focus, the Framework is illequipped to regulate GMOs created by the latest genetic editing techniques, ${ }^{61}$ such as CRISPR-Cas $9 .{ }^{62}$ Additionally, none of the U.S. regulatory approvals from the USDA, the FDA, or EPA are contingent upon regulatory approval abroad. ${ }^{63}$ Although the Coordinated Framework states that the U.S. "seeks to reduce barriers to international trade" and recognizes the need to harmonize regulatory activities among nations, the Framework also states that "the development of international guidelines . . . is premature at this time." ${ }^{64}$ This failure to account for international approvals is partially to blame for export market disruptions, including that of Syngenta. ${ }^{65}$

Although a compelling argument can be made that the consideration of international approvals is beyond the missions of U.S. agencies, ${ }^{66}$ the Syngenta litigation demonstrates the detriment of turning a blind-eye to foreign regulators. ${ }^{67}$ Even though Syngenta was in full compliance with U.S. regulatory requirements, the company still faced a costly settlement payout rooted in conflict between domestic and international regulations. ${ }^{68}$ Since the United States is the world's largest producer of biotech crops and is a net exporter of agricultural products, ${ }^{69}$ U.S. regulators should help protect American farms and agribusinesses by addressing divergences between domestic and international approvals.

59. See generally Lucas A. Westerman, Digging Up the Dirt: China's Exploitation of Transgenic Seed Approvals, 88 U. Colo. L. REv. 765, 775 (2017); Clare Althouse, Note, "Farming Out” Regulatory Responsibility: Private Parties in the Biotechnology Age, 23 Geo. InT'L EnvtL. L. REV. 421, 423, 425 (2011); Lee-Muramoto, supra note 48, at 316-17.

60. Alex Robeson, CRISP-Cas9 and Genome Editing, Duke SciPol Blog (May 17, 2017), http://scipol.duke.edu/content/crispr-cas9-and-genome-editing [https://perma.cc/LDB2-8L3H].

61. Id.

62. CRISPR-Cas9 is a genetic editing technology that allows disadvantageous genes to be deleted from an organism's genome. It is unclear how this technology will be regulated under the Coordinate Framework because - unlike traditional genetic engineering — foreign DNA is not being added to gene edited organism. $I d$.

63. Coordinated Framework for Regulation of Biotechnology, 51 Fed. Reg. 23,302, 23,308 (June 26, 1986).

64. Id. at 23,308-09.

65. See generally Goeringer, supra note 46 , at $377-80$.

66. See, e.g., What We Do, FoOD \& DRUG ADMIN., https:/www.fda.gov/aboutfda/ whatwedo/\#mission [https://perma.cc/LCU6-8WRL] (outlining the agency's general focus on domestic interests).

67. See generally Goeringer, supra note 46 , at $377-80$.

68. See generally id.

69. See Biotechnology, U.S. DEP'T AGRiculture, https://www.usda.gov/topics/ biotechnology [https://perma.cc/T26G-KL4H]. 


\section{B. International Regulation}

More than seventy nations individually regulate the commercialization of a new GMO ${ }^{70}$ This piecemeal system leads to asynchronous approvals - a growing area of concern for international grain trade. ${ }^{71}$ Even when a biotech developer submits its product to regulatory bodies at the same time, GMOs do not receive approval simultaneously around the world. ${ }^{72}$ These situations are known as asynchronous approvals. ${ }^{73}$ Ultimately, asynchronous approvals can disrupt export markets and generate liability for biotech developers. ${ }^{74}$

Time lapses between international approvals are a source of business risk and potential liability. ${ }^{75}$ Although biotechnology is used extensively in the United States, the rest of the world has been slower to adopt genetic-engineering technologies. ${ }^{76}$ Even those countries that historically accept and consume GMO crops often lag behind the United States in approving new GMO products. ${ }^{77}$ This inevitably creates a gap between U.S. commercialization and export market acceptance. ${ }^{78}$ Some countries, such as China, Russia, Taiwan, and the Philippines, stipulate that no import approval requests for GMO crops can begin until the product has been approved in the exporting country. ${ }^{79}$ This intentional postponement leaves biotech manufacturers with two options: (1) delay commercialization until all approvals have been obtained, or (2) begin commercialization in the approving country and implement stewardship practices to isolate the product from export markets. ${ }^{80}$ Both of these options are costly and inefficient. ${ }^{81}$

Economic globalization intensifies the effects of asynchronous approvals. ${ }^{82}$ Nations around the world are becoming increasingly interdependent and rely on

70. Global Approvals of GMO Crops, supra note 40.

71. Alexander J. Stein \& Emilio Rodriguez-Cerezo, Inst. for Prospective Tech. Studies, The Global Pipeline of New GMCrops: ImPliCATIONS OF ASYNCHRONOUS APPROVAL FOR INTERNATIONAL TRADE 9 (2009), http://ftp.jrc.es/EURdoc/JRC51799.pdf [https://perma.cc/ R9FL-5PQS].

72. Id.

73. Id.

74. Id.

75. Id.

76. A. Bryan Endres, Coexistence Strategies, The Common Law of Biotechnology and Economic Liability Risks, 13 DraKe J. Agric. L. 115, 127 (2008).

77. Id.

78. $I d$.

79. Rosane Nunes De Faria \& Christine Wieck, Regulatory Differences in the Approval of GMOs: Extent and Development Over Time, 15 World Trade Rev. 85, 85-108 (2016).

80. See generally Endres, supra note 76.

81. See generally id.

82. See generally STEIN \& RodRIGUEZ-CEREZO, supra note 71. 
one another for trade of commodities and services. ${ }^{83}$ For example, the United States is the world's largest producer and exporter of corn. ${ }^{84}$ As such, corn producers in the United States rely on foreign export markets to support prices, particularly in years of decreased domestic consumption or increased domestic supply. ${ }^{85}$ Similarly, corn importers, such as Japan, South Korea, and Taiwan, rely on U.S. corn production to support an expanding livestock industry. ${ }^{86}$ If a GMO crop is approved in an exporting country but not an importing country, the lack of approval is a barrier to trade. ${ }^{87}$ As the leading exporter of biotech crops, the United States is most susceptible to the effects of trade disruptions from asynchronous approvals, as are other significant exporters. ${ }^{88}$ As trade has become increasingly important to economic vitality, trade barriers, such as asynchronous approvals, have grown increasingly detrimental. ${ }^{89}$

To prevent trade disruptions from asynchronous approvals, U.S. trade associations urge manufacturers to have approvals in all major export markets before commercializing a new GMO seed..$^{90}$ However, the top export markets for U.S. grain are not necessarily consistent from year to year. ${ }^{91}$ This inconsistency makes the identification of major markets difficult. ${ }^{92}$ And, while receiving major market approval after deregulation by the appropriate U.S. agencies is an important part of trade association stewardship standards, it is not a legal requirement. ${ }^{93}$ Stewardship standards are voluntary management practices developed through industry coalitions attempting to remedy common issues, or as Thomas Redick put it, stewardship is "voluntary risk management." ${ }^{\text {" }}$ But the Syngenta litigation demonstrates that U.S. courts find these voluntary stewardship standards insufficient - after all, the lack of major market approval in China was the basis of the negligence claim against the company. ${ }^{95}$

83. Gao Shangquan, Economic Globalization: Trends, Risks, and Risk Prevention, (United Nations CDP Background Paper No. 1, 2000), http:/www.un.org/en/development/desa/policy/cdp/ cdp_background_papers/bp2000_1.pdf[https://perma.cc/YM5G-ZGBZ].

84. Corn and Other Feed Grains: Trade, U.S. DeP'T Agriculture, https://www.ers.usda. gov/topics/crops/corn/trade/ [https://perma.cc/MT6G-TNN2].

85. Id.

86. Id.

87. See generally STEIN \& RODRIGUEZ-CEREZO, supra note 71.

88. See generally Corn and Other Feed Grains: Trade, supra note 84.

89. See generally STEIN \& RODRIGUEZ-CEREZO, supra note 71.

90. Plant Biotechnology Product Launch Stewardship, CROPLifE InT'L, https://croplife.org/plant-biotechnology/stewardship-2/product-launch-stewardship/ [https://perma.cc/6DKG-9RM9].

91. See generally Export Sales Query System, U.S. DeP'T AGRiculture, https://apps.fas. usda.gov/esrquery/ [https://perma.cc/B28M-2MKM].

92. Goeringer, supra note 46 , at 382-83.

93. See generallyid. at 379 .

94. Thomas P. Redick, Stewardship for Biotech Crops: Strategies for Improving Global Consumer Confidence, 44 JuRIMETRICS J. 5, 6 (2003).

95. See In re Syngenta AG MIR162 Corn Litig., 131 F. Supp. 3d 1177 (D. Kan. 2015). 

THROUGH LITIGATION IN BIOTECHNOLOGY

Asynchronous approvals can have particularly strong impacts on trade if an importing country operates under a zero tolerance principle. ${ }^{96}$ The zero tolerance principle has been adopted by countries whose markets have demanded a GMOfree product pipeline, ${ }^{97}$ and this principle sets a remarkably stringent standard by which grain purity is measured. ${ }^{98}$ For example, the European Union operates under a zero tolerance principle, which requires that imports achieve a "technical zero" for contaminants, such as unapproved genetic material..$^{99}$ For the European Commission, a technical zero equals $0.1 \%$ or less. ${ }^{100}$ The zero tolerance principle is particularly impactful because any nation operating under the principle can reject an entire grain shipment if the shipment contains even the slightest trace of unapproved genetic material. ${ }^{101}$ In the Syngenta litigation, China's zero tolerance principle contributed to the vastness of Syngenta's liability because the principle was used to reject entire barges of grain possibly containing traces of the MIR162 trait. $^{102}$

As demonstrated by the Syngenta litigation, a technical zero for a particular GMO trait is nearly impossible to achieve if that GMO product has been commercialized in the exporting country; however, tolerance of low level presence is a less stringent purity standard widely supported by exporters. ${ }^{103}$ CropLife International, the international trade organization for the plant science industry, asserts that $100 \%$ purity is impossible in crop production. ${ }^{104}$ Because of this reality, the organization advocates for the acceptance of low level presence - a minute, acceptable level of contaminants, consistent with generally accepted agricultural and manufacturing practices in the United States. ${ }^{105}$ Low level presence can be minimized through the implementation of best management practices for the cultivation and supply chain distribution of asynchronously approved GMOs. ${ }^{106}$ But ultimately, importers recognizing the inevitability of diminutive contamination would help exporters avoid costly shipment rejections. ${ }^{107}$

Although each country can independently regulate GMO products on its own accord, industry leaders recognize the host of potential conflicts - particularly

96. STEIN \& RodrigueZ-CEREZO, supra note 71.

97. See generally Endres, supra note 76.

98. Plant Biotechnology Regulatory, supra note 19.

99. Genetically Modified Organisms Technical Zero, EuROPEAN COMM'N, https://ec.europa. eu/food/plant/gmo/post_authorisation/technical_zero_en [https://perma.cc/2GPC-FS5J].

100. $I d$.

101. StEIN \& RodRIGUEZ-CEREZO, supra note 71.

102. See generally Redick et al., supra note 2 .

103. Plant Biotechnology Regulatory, supra note 19.

104. Id.

105. Id.

106. Id.

107. Id. 
related to trade- that result from asynchronous approvals. ${ }^{108}$ Accordingly, industry leaders created The Cartagena Protocol on Biosafety, a standard for the international shipment of biotech crops. ${ }^{109}$ Nearly 200 countries have joined The Cartagena Protocol on Biosafety. ${ }^{110}$ Notably, the United States and Argentina-the first and third largest producers of GMO crops respectively ${ }^{111}$ - have not signed the protocol. ${ }^{112}$ In contrast, Mexico and Japan, the top importers of U.S. corn in $2016,{ }^{113}$ have signed. ${ }^{114}$ The prevalence of importing country signatories may indicate a need to amend the protocol to be more amiable toward exporters. ${ }^{115}$ The Protocol was an important recognition of the need for international compromise, but failure to include significant exporters renders the Protocol ineffective in its attempt to limit barriers to trade. ${ }^{116}$

In summary, the international regulation of GMOs relies on individualist polices that isolate nations and stunt trade. ${ }^{117}$ Unique regulatory timelines lead to asynchronous approvals, which in turn cause delays to commercialization and disruptions to international commerce. ${ }^{118}$ Although biotechnology trade associations urge companies to minimize the potential for trade disruptions by achieving major market approvals prior to commercialization, stewardship standards are voluntary guidelines which a company may choose not to follow. ${ }^{19}$ Finally, the effects of asynchronous approvals are exacerbated under the stringent zero tolerance principle purity standard. ${ }^{120}$ Although some nations have come together in hopes of standardizing guidelines for the trade of GMOs, the Cartagena Protocol has yet to garner support from two of the world's largest exporters of GMO grain. ${ }^{121}$ Ultimately, the international regulation of GMOs is a source of unpredictable risk for biotech developers. ${ }^{122}$

108. Stein \& Rodriguez-CEREzo, supra note 71.

109. The Cartagena Protocol on Biosafety, UnITED NATIONS, https://bch.cbd.int/protocol [https://perma.cc/8NP4-Y4VX].

110. Id.

111. Biotech Crop Highlights in 2016, InT'L SERV. FOR ACQUiSITION AgRi-BIOTECH APPLICATIONS, http://www.isaaa.org/resources/publications/pocketk/16/ [https://perma.cc/6GX2VU23].

112. The Cartagena Protocol on Biosafety, supra note 109.

113. Leading Buyers of U.S. Corn 2016, STATISTA, https://www.statista.com/statistics/254288/ top-us-corn-buyers-by-country/ [https://perma.cc/6BT8-VLSM].

114. The Cartagena Protocol on Biosafety, supra note 109.

115. See generally Thomas P. Redick, The Cartagena Protocol on Biosafety: Precautionary Priority in Biotech Crop Approvals and Containment of Commodities Shipments, 18 CoLO. J. INT'L ENVTL. L. \& POL'Y 51, 56-58 (2007).

116. See generally id.

117. See generally Plant Biotechnology Regulatory, supra note 19.

118. Stein \& Rodriguez-CEREzo, supra note 71.

119. Plant Biotechnology Product Launch Stewardship, supra note 90.

120. Stein \& RodrigueZ-CEREZO, supra note 71.

121. The Cartagena Protocol on Biosafety, supra note 109.

122. See generally STEIN \& RodRiguEZ-CEREZO, supra note 71. 

THROUGH LITIGATION IN BIOTECHNOLOGY

\section{THE ROLE OF LITIGATION IN REGULATING BIOTECHNOLOGY}

\section{A. Regulation through Litigation: An Overview}

The use of litigation to influence regulatory policy-what scholars have termed "regulation through litigation"- has garnered mixed reactions from commentators. ${ }^{123}$ Regulation through litigation began in the 1990s and theorizes that enforcement actions and the threat of catastrophic loss can impose new substantive obligations on regulated industries. ${ }^{124}$ Regulation through litigation allows agencies and private actors to impose additional requirements on an industry while simultaneously bypassing normal administrative law procedures, such as notice-and-comment rulemaking. ${ }^{125}$ Regulation through litigation influences substantive regulatory requirements in many industries, such as gun manufacturing, ${ }^{126}$ tobacco sales, and milk production, to name a few. ${ }^{127}$

Regulation through litigation can effectively shape public policy because it "can frame issues in new ways, give them greater prominence on the agendas of regulatory institutions, uncover policy-relevant information, and mobilize reform advocates." 28 But regulation through litigation can also be "unnecessarily complex, protracted, costly, unpredictable, and inconsistent." ${ }^{\prime 29}$

Regulation through litigation influences policy making in six distinct ways. ${ }^{130}$ Regulation through litigation frames issues in terms of institutional failure and highlights the need for institutional reform. ${ }^{131}$ Additionally, regulation through litigation generates relevant policy making information and draws attention to issues by placing them on the agendas of policy making institutions. ${ }^{132}$ The practice encourages self-regulation and allows for diverse regulatory approaches in different jurisdictions. ${ }^{133}$ Most importantly, regulation through litigation fills gaps in statutory or administrative regulatory schemes. ${ }^{134}$ Regulation through litigation requires that the litigation identify an issue, generate information about

123. Timothy D. Lytton, Using Tort Litigation to Enhance Regulatory Policy Making: Evaluating Climate-Change Litigation in Light of Lessons from Gun-Industry and Clergy-SexualAbuse Lawsuits, 86 TEX. L. REV. 1837, 1837 (2008).

124. Andrew P. Morriss et al., Choosing How to Regulate, 29 HARv. EnVtL. L. Rev. 179, 181 (2005).

125. Goeringer, supra note 46 , at 380.

126. See Lytton, supra note 123.

127. See Goeringer, supra note 46 , at $380-82$.

128. Lytton, supra note 123, at 1837.

129. Id.

130. Id. at 1838 .

131. Id.

132. Id.

133. Id.

134. Id. 
the issue, garner interest in the issue from policymakers and the public, and ultimately offer solutions for deficiencies in the current regulatory system. ${ }^{135}$

Regulation through litigation is an effective policymaking tool when it generates a narrative that stimulates regulatory reform, ${ }^{136}$ but public involvement is limited in regulation through litigation compared to notice-and-comment rulemaking. ${ }^{137}$ Additionally, regulation through litigation does not work in all regulatory contexts. ${ }^{138}$ To be effective, the regulated industry must be concentrated so that litigation against individual firms can effectively substitute for industry-wide rule promulgation. ${ }^{139}$

Historically, litigation has supplemented statutory law by settling disputes over specific sets of facts for particular parties. ${ }^{140}$ Conversely, regulation through litigation manipulates litigation - $\mathrm{a}$ vehicle for redressing individualized harms - by using the American adversarial system as means to impose new, substantive requirements on entire industries. ${ }^{141}$

Regulation through litigation represents a conflict between traditional U.S. tort law and the U.S. regulatory system. ${ }^{142}$ In situations where regulation through litigation may arise, the government has made the decision not to regulate a particular activity through the democratic political process. ${ }^{143}$ This decision may, for example, be based on the absence of need for regulation, projected costs and burdens of regulation, or the desire of the American public - as conveyed through elected representatives - to allow an industry to remain unregulated. ${ }^{144}$ Regulation through litigation occurs when plaintiffs suggest to courts, via law suits, that the judiciary should effectively regulate an industry through the threat of imposing broad liability against entities in that industry. ${ }^{145}$ Although regulation through litigation does have the power to exert positive influence on policymaking and has been attempted with some success in multiple industries, courts have generally recognized that the practice undercuts the basis of the American democratic system. ${ }^{146}$ America's democracy counts on omissions of the legislative and executive branches being corrected through the ballot box. ${ }^{147}$

As the judiciary itself has recognized, lawsuits are not the ideal mechanism

135. See id. at 1842-58.

136. Id. at 1870 .

137. Morriss et al., supra note 124, at 183.

138. Id.

139. Id.

140. Alexandra D. Lahav, The Roles of Litigation in American Democracy, 65 EMORY L.J. 1657, 1658 (2016).

141. Goeringer, supra note 46 , at $380-81$.

142. Victor E. Schwartz \& Christopher E. Appel, Government Regulation and Private Litigation: The Law Should Enhance Harmony, Not War, 23 B.U. PUB. INT. L.J. 185, 187 (2014).

143. Id.

144. Id.

145. Id.

146. Id. at 198 .

147. Id. 
for creating industry regulations. ${ }^{148}$ The purpose of the civil judicial system is the compensation of individuals wrongfully injured by another's conduct. ${ }^{149}$ The promulgation of regulation is better suited to the executive and legislative branches than the judicial branch because those branches have the opportunity to see beyond the merits of an individual case and assess the impact of a given rule on society at-large. ${ }^{150}$ Regulation through litigation does have value in generating relevant policy information and support for policy reform, ${ }^{151}$ but meaningful and lasting regulatory reform is better suited to the non-judicial branches of government because of the narrow purview of litigating an individual case. ${ }^{152}$

\section{B. Syngenta MIR162 as Regulation through Litigation}

Recognizing the economic detriment of asynchronous approvals, the Syngenta litigation effectively created a new regulation for biotech developers. ${ }^{153}$ As explained above, regulation through litigation begins with a gap in regulation, which is often accompanied by a wave of support for policy change. ${ }^{154}$ U.S. regulatory approvals do not consider whether international approvals have been obtained and do not account for asynchronous approvals generally. ${ }^{155}$ This is the regulatory gap the Syngenta plaintiffs filled via litigation. ${ }^{156}$ Additionally, the Syngenta litigation garnered immense interest among farmers; roughly 7,300 plaintiffs joined the Kansas bellwether trial alone. ${ }^{157}$ Thus, the two hallmark requirements of regulation through litigation were fulfilled. ${ }^{158}$ By claiming that Syngenta negligently commercialized its product in the United States prior to receiving major market approval in China, the plaintiffs demonstrated that biotech developers can be held accountable for selling a product despite full U.S. regulatory approval. ${ }^{159}$ This litigation - and its tremendous cost -effectively impose a new regulatory responsibility for biotechnology companies prior to

148. $I d$.

149. Id.

150. Id. at 198-99.

151. Lytton, supra note 123 , at 1841.

152. Schwartz \& Appel, supra note 142, at 197-99.

153. Goeringer, supra note 46, at 382-84.

154. See discussion supra Part III.A.

155. See generally Coordinated Framework for Regulation of Biotechnology, 51 Fed. Reg. 23,302 (June 26, 1986).

156. Goeringer, supra note 46, at 382.

157. Jim Suhr, Kansas Jury Awards \$218 Million to Farmers in Syngenta Lawsuit, DeS MoINES REG. (June 23, 2017, 2:32 PM), https:/www.desmoinesregister.com/story/money/ agriculture/2017/06/23/kansas-jury-awards-218-million-farmers-syngenta-lawsuit/424618001/ [https://perma.cc/9PH5-28F5].

158. Lytton, supra note 123, at 1841; Schwartz \& Appel, supra note 142.

159. Goeringer, supra note 46 , at 382 . 
commercializing new products: the duty to obtain major market approval. ${ }^{160}$ After all, Syngenta's settlement ultimately amounted to $\$ 1.51$ billion as justification for delaying the commercialization of a new product until all potential major markets have given full regulatory approval. ${ }^{161}$

Although trade associations have long published stewardship standards urging companies to obtain major market approval for biotech products prior to commercialization, these stewardship standards do not have the force of law. ${ }^{162}$ In the course of the Syngenta litigation, plaintiffs demonstrated that major market approvals warrant more enforcement than voluntary stewardship standards. ${ }^{163}$ Now, obtaining major market approvals is effectively a regulatory requirement for biotech companies wanting to avoid litigation. ${ }^{164}$

\section{THE SHORTCOMINGS OF ClASS ACTIONS AS A REGULATORY MECHANISM}

Although litigation serves as an effective vehicle to enforce existing regulation, reliance on litigation to produce new, substantive biotech regulations presents three primary shortcomings: (1) failure to remedy asynchronous approvals, (2) incomplete regulation, and (3) vulnerability for U.S. farms and agribusinesses.

\section{A. Failure to Remedy Asynchronous Approvals}

Regulation through litigation develops within a gap in existing regulation-in this case, asynchronous approvals. Although asynchronous approvals are clearly a source of trade disruption in need of remedy, the Syngenta litigation and its de facto regulation fail to adequately remedy the fundamental problem. ${ }^{165}$ The Syngenta litigation and other similarly situated cases force companies to account for asynchronous approvals to avoid liability from trade disruptions, ${ }^{166}$ but domestic class action litigation is ill-equipped to remedy conflicts with regulatory policy abroad. ${ }^{167}$

Class actions are effective tools for mobilizing public opinion, ${ }^{168}$ but rules reached through a well-rounded coalition of interested parties rather than two sides of an adversarial lawsuit promise to be better suited to long-run regulatory success. ${ }^{169}$ Regulation through litigation certainly has a place in policy

160. Id.

161. Begemann, supra note 1; Goeringer, supra note 46, at 382-84.

162. See generally Plant Biotechnology Product Launch Stewardship, supra note 90.

163. See generally Goeringer, supra note 46 , at 382-84.

164. See generallyid.

165. See, e.g., In re Syngenta AG MIR 162 Corn Litig., 131 F. Supp. 3d 1177 (D. Kan. 2015) (noting that plaintiffs claim Syngenta is singularly liable).

166. Goeringer, supra note 46 , at 382.

167. See Syngenta, 131 F. Supp. 3d at 1191 (noting that the court recognizes a duty of care for the company but does not propose a remedy for conflicts between inter-connected markets).

168. Lytton, supra note 123.

169. Schwartz \& Appel, supra note 142, at 198-99. 

THROUGH LITIGATION IN BIOTECHNOLOGY

development, particularly in supplementing developed regulatory schemes. ${ }^{170}$ However, regulation through litigation's fatal flaw is the inability to consider perspectives from the entire interested constituency. ${ }^{171}$ Although class action litigation does bring together a great number of plaintiffs to a case, ${ }^{172}$ class actions still bring few parties to the courtroom to be heard. ${ }^{173}$ Class actions undoubtedly interest and indirectly involve many, but they are resolved by a few: the lead plaintiff, the defendant, and their respective attorneys. ${ }^{174}$

Conversely, traditional regulatory reform efforts rely on a democratic process, accounting for all those who wish to make their opinions heard. ${ }^{175}$ The remedy for asynchronous approvals will likely require domestic and international reform of biotechnology regulations, ${ }^{176}$ but class action litigation is incapable of fully capturing the interested domestic constituency in the decision-making process - much less interested constituencies from abroad. ${ }^{177}$

Tort litigation is retrospective, ${ }^{178}$ but addressing asynchronous approvals will require proactive international compromise. ${ }^{179}$ As discussed above, some countries purposely delay the regulatory approval process for new GMO products until approval in the exporting country has been achieved. ${ }^{180}$ While some may argue that this policy simply follows a cautious approach to the approval of new technologies, others assert that this asymmetry creates a powerful tool for trade manipulation and economic gain. ${ }^{181}$ For example, in the Syngenta litigation, the

170. Lytton, supra note 123.

171. See Manhattan Inst., Regulation Through Litigation: Assessing the Role of Bounty Hunters and Bureaucrats in the American Regulatory Regime 2 (2000), https://www.manhattan-institute.org/pdf/mics2.pdf [https://perma.cc/AP5Q-A5LF].

172. See Class Action: An Overview, Cornell L. ScH., https://www.law.cornell.edu/wex/ class_action [https://perma.cc/PQ2L-PJP9].

173. See generally Class Action Cases, FIndLAw, http://itigation.findlaw.com/legalsystem/class-action-cases.html [https://perma.cc/WUL9-CRK4].

174. See generally id. (noting that the lead plaintiff is responsible for notifying other members of the class of developments in the litigation).

175. MANHATtAn InSt., supra note 171.

176. Guillaume P. Gruère, International Trade-Related Regulations of GM Food, INT'L FOOD POL'y RES. INST. 2 (2007), https://www.cbd.int/doc/external/mop-04/ifpri-pbs-policy06-en.pdf [https://perma.cc/J87X-KKUE].

177. See generally Daniel P. Shapiro \& Gail H. Kim, US Class Actions with Non-US Citizens and Class Members: Fairness Issues Considered, 11 Bus. L. INT'L 39, 39-41 (2010) (noting the difficulty of joining a class action as a non-U.S. citizen).

178. Tort, CoRnell L. ScH., https://www.law.cornell.edu/wex/tort [https://perma.cc/6G7PRMDQ].

179. See generally Int'l Statement on Low Level Presence, U.S. DeP'T AgRiculture (Mar. 22, 2012), https://www.fas.usda.gov/international-statement-low-level-presence [https://perma.cc/G9P8-WEX2].

180. Nunes De Faria \& Wieck, supra note 79.

181. See generally Westerman, supra note 59, at 766-71. 
Chinese government was able to exploit asynchronous approval with the United States and reject all shipments of U.S. corn supposedly on the grounds of genetic contamination. ${ }^{182}$ However, China accepted nearly one million tons of corn containing traces of the MIR162 gene before deciding to reject U.S. shipments on those grounds. ${ }^{183}$ The rejection of U.S. corn caused a surplus on the world market, which triggered a drop in corn prices worldwide. ${ }^{184}$ This allowed China to back out of contracts to buy higher-priced U.S. corn and instead import lowerpriced grain from South American countries. ${ }^{185}$ Additionally, the argument that China rejected the corn on the grounds of genetic contamination is unconvincing because China also accepted corn containing the same MIR162 trait from Argentina, yet it did not block imports from that country. ${ }^{186}$ With perverse economic incentives lining the road to synchronized approvals, it will be difficult to bring all necessary parties to the proactive bargaining table, ${ }^{187}$ much less to the retrospective U.S. courtroom. ${ }^{188}$

\section{B. Incomplete Regulation}

The Syngenta litigation created a new but incomplete regulation for biotechnology. ${ }^{189}$ This litigation imposed a duty to either obtain major market approval for a new biotech product prior to commercialization or risk the threat of enormous class action liability. ${ }^{190}$ Unfortunately, the Syngenta litigation failed to provide adequate guidance for companies as to which markets constitute "major markets" under this new regulation. ${ }^{191}$ As discussed above, failure to adequately explore the implications of a new rule is one of the drawbacks to imposing regulation through litigation instead of through notice-and-comment rulemaking. ${ }^{192}$ Following the Syngenta litigation, it is unclear where individual courts will draw the line when defining major markets. ${ }^{193}$ Uncertainty colors whether companies will be sufficiently protected from liability by obtaining approvals in major markets at the time of commercialization or whether the judiciary will also expect approvals in potential or projected major markets. ${ }^{194}$

182. Henry I. Miller, China's Threat to American Farm Exports, Hoover Inst. (Mar. 18, 2014 ), https://www.hoover.org/research/chinas-threat-american-farm-exports [https://perma.cc/XEV9-ADKY].

183. Id.

184. Id.

185. Id.

186. Westerman, supra note 59, at 790.

187. See generally Miller, supra note 182.

188. See Tort, supra note 178.

189. See generally Goeringer, supra note 46 , at 382-84.

190. Id. at 382.

191. Id.

192. Supra Part II.A.

193. Goeringer, supra note 46 , at 382 .

194. Id. 

THROUGH LITIGATION IN BIOTECHNOLOGY

Additionally, companies are left wondering whether reliance on improper trade projections is potentially a form of negligence itself. ${ }^{195}$ The Syngenta litigation - like many other instances of regulation through litigation - created an incomplete rule of law that generates uncertainty in the regulated industry. ${ }^{196}$

\section{Vulnerability for American Farms and Businesses}

The United States is the world's top producer of biotech crops,${ }^{197}$ and class action litigation is largely an American concept. ${ }^{198}$ This combination creates a unique vulnerability for American farms and agribusinesses, especially considering the waning effectiveness of class action litigation. ${ }^{199}$

The United States is a leader in biotechnology acceptance and adoption. ${ }^{200}$ As of 2018 , crops produced through genetic engineering accounted for $90 \%$ of corn, $91 \%$ of cotton, and $94 \%$ of soybeans planted in the United States. ${ }^{201}$ Additionally, the United States is the world's largest exporter of agricultural products, ${ }^{202}$ with more hectares of biotech crops than any other country. ${ }^{203}$ Because other nations do not produce biotech crops to the scale of U.S. production, biotech litigation has a greater impact in the United States than in any other food production system globally. ${ }^{204}$

American courts are not the only judicial system offering a means for many plaintiffs to join together in bringing a tort case, but the threat of class action liability is most significant in the United States. ${ }^{205}$ Class action litigation originated in English Courts of Equity, ${ }^{206}$ but modern class action litigation is

195. $I d$. at 383 .

196. Id. at 382-83.

197. Biotechnology, supra note 69.

198. Class Action: An Overview, supra note 172 (noting the Federal Rules of Civil Procedure were promulgated in 1938).

199. See generally Andrew J. Pincus, U.S. Chamber Inst. for Legal Reform, Unstable Foundation: Our Broken Class Action System and How to FiX It 1-2 (2017), http://www.instituteforlegalreform.com/uploads/sites/1/UnstableFoundation_Web_10242017.pdf [https://perma.cc/5U6N-H97K].

200. Biotechnology, supra note 69.

201. Recent Trends in GE Adoption, U.S. DeP'T Agriculture (July 16, 2018), $\mathrm{https}$ //www.ers.usda.gov/data-products/adoption-of-genetically-engineered-crops-in-the-us/recenttrends-in-ge-adoption.aspx [https://perma.cc/V2MF-QMHP].

202. Biotechnology, supra note 69.

203. STEIN \& RodRigueZ-CEREZo, supra note 71.

204. See generally Biotechnology, supra note 69.

205. Kevin LaCroix, Class Actions Around the World, D\&O Diary (Sept. 27, 2012), https:/www.dandodiary.com/2012/09/articles/international-d-o/class-actions-around-the-world/ [https://perma.cc/EZE6-57HL].

206. Class Action: An Overview, supra note 172. 
most often associated with the litigious legal culture of the United States. ${ }^{207}$ America has the highest liability costs as a percentage of Gross Domestic Product of any developed nation, ${ }^{208}$ and class actions are an expensive problem for corporations doing business in the U.S. ${ }^{209}$ Because class actions are so prominent in the United States, these cases are a handicap to U.S. farmers and biotech developers. ${ }^{210}$

Undoubtedly, class action litigation has its roots in meritorious efforts to protect societal interests by compensating class members and deterring wrongful conduct. ${ }^{211}$ However, modern class actions often drift from their intended purpose and net limited social utility. ${ }^{212}$ For example, absent class members - the plaintiffs who are not the class representatives - rarely see payments ${ }^{213}$ from class actions. ${ }^{214}$ Additionally, the frequency by which class actions are filed in the United States has created a perception for many business leaders that litigation is an unavoidable cost of doing business in the U.S. ${ }^{215}$ When businesses feel litigation is inevitable - regardless of the company's efforts to act lawfully - then companies have little incentive to spend resources on compliance. ${ }^{216}$ The limited effectiveness of class action litigation often leaves plaintiffs unsatisfied and companies perplexed as how to best manage the indiscriminate business risk from these lawsuits. ${ }^{217}$

Because the Syngenta litigation created liability for selling a product to U.S. farmers with full U.S. approval, it demonstrates how U.S. courts can burden business and trade. ${ }^{218}$ The Chinese rejection of U.S. corn was indisputably followed by a decrease in the price of the grain; ${ }^{219}$ however, the Syngenta litigation placed the blame squarely on the company without recognizing the

207. LaCroix, supra note 205.

208. Int'l Comparisons of Litigation Costs: Canada, Europe, Japan, and the United States, U.S. CHAMBER INST. FOR LEGAL REFORM (June 14, 2013), http://www.instituteforlegalreform.com/ research/international-comparisons-of-litigation-costs-europe-the-united-states-and-canada [https://perma.cc/LHS2-WDEN].

209. J. Mark Ramseyer \& Eric B. Rasmusen, Comparative Litigation Rates, (Harv. John M. Olin Ctr. for Law, Econ., \& Bus. Discussion Paper No. 681, 2010), http://www.law.harvard.edu/ programs/olin_center/papers/pdf/Ramseyer_681.pdf [https://perma.cc/NR5M-885M].

210. Goeringer, supra note 46 , at 380-83.

211. PINCUS, supra note 199, at 1-2.

212. Id.

213. The Consumer Financial Protection Bureau found that $87 \%$ of a sample of 562 resolved class actions resulted in no benefit to absent class members. These cases were either dismissed by the court or settled with the named plaintiff only. PINCUS, supra note 199, at 3.

214. PINCUS, supra note 199, at 1-2.

215. Id.

216. Id.

217. See generallyid.

218. See generally Goeringer, supra note 46, at 382 .

219. See In re Syngenta AG MIR162 Corn Litig., 131 F. Supp. 3d 1177 (D. Kan. 2015). 

THROUGH LITIGATION IN BIOTECHNOLOGY

culpability of the Chinese Ministry of Agriculture. ${ }^{220}$ By giving credence to the class's claim, the court created a massive potential liability for all biotech developers wanting to sell to U.S. farmers in the future. ${ }^{221}$ The threat of class action litigation is a new barrier to entry in the U.S. biotech market, ${ }^{222}$ which is the largest market for biotech crops in the world. ${ }^{223}$

Class action litigation creates a competitive disadvantage for U.S. producers because these cases potentially prevent U.S. farmers from accessing the latest and best seed technologies even after domestic approval. ${ }^{224}$ Because countries outside the United States lack such aggressive class action litigation, corporations may choose to market their products in other nations with a diminished threat of litigation. ${ }^{225} \mathrm{GMO}$ adoption has saved farmers time, reduced insecticide use, and enabled the use of less toxic herbicides. ${ }^{226}$ If other nations can access the latest biotechnology and U.S. farmers cannot due to the threat of litigation, then U.S. farmers will lose out on a competitive advantage. ${ }^{227}$ Further, if companies cannot sell a biotech product in the country with the highest rate of biotech adoption for fear of class action liability, companies will lose a significant customer base - inevitably decreasing a product's return on investment and stifling new product development. ${ }^{228}$ After all, what company wants to spend $\$ 100$ million $^{229}$ to create a new biotech product and another $\$ 1.51$ billion to sell it? $?^{230}$

\section{SOLUTIONS}

This section overviews three potential solutions to the problem of asynchronous approvals, one of which is a business-driven solution and two of which are legal solutions. On the business side, one solution is channeling and stewardship in the domestic supply chain. This solution allows the biotech industry to commercialize an asynchronously-approved GMO while limiting the threat of trade disruption. Unfortunately, the world's current bulk-commodity infrastructure is poorly equipped to implement identity-preservation attempts; ${ }^{231}$

220. See generally Westerman, supra note 59.

221. Goeringer, supra note 46 , at 382-83.

222. Id.

223. Biotechnology, supra note 69.

224. Westerman, supra note 59, at 792-795.

225. Ramseyer \& Rasmusen, supra note 209.

226. Jorge Fernandez-Cornejo et AL., U.S. Dep't Agriculture, Genetically ENGINEERED CROPS IN THE UNITED STATES (2014), https://www.ers.usda.gov/webdocs/ publications/45179/43668_err162.pdf?v=0 [https://perma.cc/XAS7-FZPW].

227. Miller, supra note 182.

228. Id.

229. Id. (noting the $\$ 100$ million cost of developing a new biotech seed).

230. Begemann, supra note 1 (noting that Syngenta paid $\$ 1.51$ billion to settle this class action)

231. The Unknown Costs of Food Production: One Farmer's Perspective on the Impacts on 
therefore, a legal solution is necessary. On the legal side, there is a need for international harmonization of GMO regulations. This harmonization could be accomplished by vesting regulatory authority in one centralized organization or by amending the Cartagena Protocol.

\section{A. Channeling and Stewardship}

The Syngenta litigation created a new regulation for biotechnology but leaves businesses with little guidance in defining major markets under that regulation. ${ }^{232}$ As an alternative to speculating about which market approvals are necessary prior to commercialization, biotechnology companies could take steps to market a product and keep it solely within the United States or other approving nation. ${ }^{233}$ This practice is known as channeling and often requires farmers purchasing biotech seed to sign a stewardship agreement that the crop will only be delivered to non-export locations. ${ }^{234}$ Channeling a product to stay in the United States allows manufacturers to access the largest biotech market, ${ }^{235}$ while limiting concerns about asynchronous approvals. ${ }^{236}$

Unfortunately, channeling a commodity grain is problematic because the grain harvested from fields in the fall is not the only exportable product from the crop. ${ }^{237}$ For example, corn can be processed into derivative products such as dried distillers grain and solubles, corn meal, or corn flour. ${ }^{238}$ Because of the market for secondary products, it is entirely possible for a farmer to abide by his agreement to deliver the grain to a non-export location, such as a bourbon distillery, and the crop still eventually make its way overseas as a derivative product. ${ }^{239}$ Grain processors also incur a tremendous segregation burden to ensure identity preservation and prevent comingling of a single corn variety. ${ }^{240}$ Traditionally, individual farmers deliver grain to elevators where their grain is comingled with grain from all of the other farmers who deliver to that location. ${ }^{241}$ Separating particular grain varieties based on a GMO trait's regulatory approvals would require elevators to change their intake infrastructure, maintain separate storage bins for each variety, and ultimately destroy the commoditized nature of the

Food Production Costs of Labeling Foods Produced through Biotechnology, InT'L Food INFo. COUNCIL Found. (July 10, 2014), http://www.foodinsight.org/newsletters/unknown-costs-foodproduction-one-farmer\%E2\%80\%99s-perspective-impacts-food-production-costs [https://perma.cc/A92H-C3J9] [hereinafter The Unknown Costs of Food Production].

232. Goeringer, supra note 46 , at 383.

233. Id.

234. $I d$.

235. FERNANDEZ-CORNEJO ET AL., supra note 226.

236. Westerman, supra note 59, at 802-804.

237. Goeringer, supra note 46 , at 383.

238. Id.

239. Endres, supra note 76, at 129-30.

240. Id. at 130-31.

241. The Unknown Costs of Food Production, supra note 231. 

THROUGH LITIGATION IN BIOTECHNOLOGY

crop. ${ }^{242}$ Additionally, physical channeling methods can be rendered useless in the event of pollen drift where one asynchronously-approved plant cross pollinates a fully-approved variety in the neighboring field. ${ }^{243}$ In these instances a farmer may believe he is delivering an approved variety to the elevator when in fact the grain contains unapproved genetic material. ${ }^{244}$ Finally, human error can make channeling an arduous goal ${ }^{245}$ because it is difficult, if not impossible, to distinguish one variety of corn from another simply by looking at it. ${ }^{246}$ As a result, inadvertent comingling is nearly impossible to identify without scientific testing. ${ }^{247}$ These scenarios demonstrate why the supply chain practices used to prevent genetic contamination are so difficult to enforce and why a technical zero is so difficult to achieve. ${ }^{248}$

\section{B. International Harmonization}

Asynchronous approvals are the root cause of liability for trade disruption. ${ }^{249}$ If regulatory approval processes can be standardized worldwide, potential disruptions to technological advancement and trade can be minimized. ${ }^{250}$

Regulatory standardization requires a balance of regulatory efficiency with respect for each sovereign nation's autonomy. ${ }^{251}$ Social, economic, and political influences impact the level of acceptance each nation is willing to assign to biotechnology. ${ }^{252}$ For example, the United States greeted biotechnology with ready acceptance, while the European Union met GMO food with skepticism and hesitancy. ${ }^{253}$ Because the technology differs in acceptance worldwide, regulatory standards from the World Trade Organization ("WTO") are not given the same effect when implemented by individual nations. ${ }^{254}$ For example, under the Agreement on the Application of Sanitary and Phytosanitary Measures, WTO asserts that regulations should be science based, proportional to risk,

242. Id.

243. Endres, supra note 76, at 129.

244. Id.

245. Id.

246. See generally GMO Testing, ENVIROLOGIX, https://www.envirologix.com/gmo-testing/ [https://perma.cc/8CUA-D4NP].

247. See generally id.

248. Plant Biotechnology Regulatory, supra note 19.

249. Stein \& RodrigueZ-CEREZo, supra note 71.

250. See generally id.

251. See generally Nicholas Kalaitzandonakes et al., The ImpaCt of Asynchronous Approvals for Biotech Crops on Agricultural Sustainability, Trade, AND InNOvation (2016), http://www.cast-science.org/download.cfm?PublicationID=284473\&File= 78F2B672712CC6BAD39DE5E2E50ECA5A.cfusion [https://perma.cc/NY86-YN67].

252. See generallyid.

253. Redick, supra note 115 , at 61 .

254. KALAITZANDONAKES ET AL., supra note 251, at 7. 
nondiscriminatory, and applied in a predictable and timely manner in order to ensure that all market participants benefit. ${ }^{255}$ But the Syngenta litigation exemplifies a lack of predictability in the approval process. ${ }^{256}$ Syngenta submitted its dossier for Chinese review in 2010 and expected to have the country's import approval in 2012. ${ }^{257}$ Unfortunately for Syngenta, the company's predictions were wrong and the product was not approved until 2014. ${ }^{258}$ While WTO has promulgated reasonable standards, disparity in the interpretation of these standards has increased over the past two decades. ${ }^{259}$

Although the WTO standards are useful, foundational guidance, true harmonization will require more than guiding principles. Instead, governments should seek to end asynchronous approvals by vesting regulatory authority in one centralized organization for biotechnology. Alternatively, amending the Cartagena Protocol could be a preliminary step toward international harmonization.

1. The Centralized Organization Approach.-As an alternative to more than seventy nations individually formulating biotechnology regulations, countries involved in the trade of biotech grains could vest regulatory authority in one centralized organization. An example of this type of organization is the World Organization for Animal Health. ${ }^{260}$ This organization, which still goes by its historical acronym, OIE, is an intergovernmental organization tasked with improving animal health worldwide. ${ }^{261}$ The organization is formally recognized by WTO, and is managed by an assembly of delegates designated by the governments of all member countries. ${ }^{262}$ Notably, OIE's success relies on collaboration between member nations to optimize animal disease control and prevention. ${ }^{263}$ OIE helps member nations implement WTO's Agreement on Sanitary and Phytosanitary Measures. ${ }^{264}$ OIE also cooperates with producer

255. The WTO Agreement on the Application of Sanitary and Phytosanitary Measures, WorLD TRADE ORG., https://www.wto.org/english/tratop_e/sps_e/spsagr_e.htm [https://perma.cc/GJ8S34SD].

256. Agrisure Viptera, Argisure Viptera \& China Import Approval FAQs ( 2014), http://www.syngenta-us.com/viptera_exports/images/viptera_china_qa.pdf[https://perma.cc/V65MQJPM].

257. Id.

258. Niu Shuping \& Fayen Wong, Syngenta Confirms it has Received Chinese Approval for MIR 162 Corn Imports, St. LouIS Post DisPatch (Dec. 22, 2014), http://www.stltoday.com/ business/local/syngenta-confirms-it-has-received-chinese-approval-for-mir-corn/article_9b2f300e4d2f-5804-a671-d88893aed014.html [https://perma.cc/V55R-7RQ7].

259. KALAITZANDONAKES ET AL., supra note 251 , at 7.

260. About us, WORLd ORG. FOR ANIMAL HEAlth, http://www.oie.int/about-us/ [https://perma.cc/3NG7-6HNF].

261. Id.

262. Id.

263. $I d$.

264. Support to OIE Members, World ORG. FOR ANIMAL HeALTH, http://www.oie.int/supportto-oie-members/ [https://perma.cc/DFJ5-GJJY]. 

THROUGH LITIGATION IN BIOTECHNOLOGY

groups, consumer groups, and non-governmental organizations in the development and implementation of OIE's recommended practices and trade standards. ${ }^{265}$ OIE has little authority to force member nations into compliance with OIE's standards in the event of an animal disease outbreak. ${ }^{266}$ However, member nations realize it is in their best interests to comply with OIE's recommendations and submit to the organization's expertise because OIE's policies are designed to control the outbreak, prevent spread of the disease to other member nations, and ultimately protect public health. ${ }^{267}$ These are important, time-sensitive objectives, and member nations recognize the value of OIE resources in achieving their success. ${ }^{268}$

Another example of a centralized organization is the International Council for Harmonization of Technical Requirements for Pharmaceuticals for Human Use ("ICH"). ${ }^{269}$ ICH brings together regulatory authorities and pharmaceutical industry leaders from around the globe to set scientific and technical requirements for drug registrations. ${ }^{270}$ International harmonization is achieved through the development of ICH guidelines via a process of scientific consensus, and then these guidelines are adopted by regulators in each participating nation. ${ }^{271}$ ICH was established as an international non-profit association under Swiss law in 2015. ${ }^{272}$

The regulatory members of $\mathrm{ICH}$ have the right to attend $\mathrm{ICH}$ assembly meetings, appoint experts in working groups, and vote in the assembly; in turn, the regulatory members have a duty to implement $\mathrm{ICH}$ guidelines. ${ }^{273}$ This duty of implementation is a key to ICH's success. ${ }^{274} \mathrm{ICH}$ uses a five-step procedure to achieve harmonization. ${ }^{275}$ First, an expert working group builds consensus to prepare a draft technical document. ${ }^{276}$ Second, the working group submits the document to the assembly to confirm consensus and draft the regulatory

265. Cooperation Agreements, World ORg. FOR ANimal HeAlth, http://www.oie.int/aboutus/key-texts/cooperation-agreements/ [https://perma.cc/YAK5-R8QP].

266. See generally Support to OIE Members, supra note 264.

267. Our Missions, WORLd ORg. FOR ANIMAL HEAlth, http://www.oie.int/ index.php?id=53\#c200 [https://perma.cc/YN7Z-LP82].

268. Id.

269. Mission, INT'L COUNCIL FOR HARMONISATION, http://www.ich.org/about/mission.html [https://perma.cc/ACG7-9ZMA].

270. $I d$.

271. Id.

272. Id.

273. Theresa M. Mullin, Director, Office of Strategic Programs, Update on ICH Reforms, (May 15, 2015), https://www.fda.gov/downloads/Drugs/NewsEvents/UCM446914.pdf [https://perma.cc/RM3E-LB82].

274. Mission, supra note 269.

275. Formal ICH Procedure, InT'L COUnCIL FOR HARMONISATION, http://www.ich.org/ products/process-of-harmonisation/formalproc.html\#step-5 [https://perma.cc/RZD3-S7P9].

276. Id. 
guidelines. ${ }^{277}$ Third, regulators consult on the draft guidelines, provide comments, and a final set of guidelines is written. ${ }^{278}$ Fourth, the assembly must agree that there is sufficient consensus and adopt the final guidelines. ${ }^{279}$ Fifth, the guidelines are implemented by participating countries according to the rulemaking procedures of each sovereign nation. ${ }^{280}$

Scientific consensus and the duty of implementation are critical to the success of ICH. ${ }^{281}$ As discussed above, the acceptance of biotechnology differs around the globe. ${ }^{282}$ This is likely to stifle the scientific consensus-building that is critical to the five-step process. However, relying on a procedure similar to that of ICH would also be an important opportunity to evaluate data relating to the safety and efficacy of biotechnology - potentially eliminating some societal misperceptions about GMOs. Additionally, many nations, including the United States, vest regulatory authority over GMOs to more than one national agency. ${ }^{283}$ This could make implementation more difficult in the biotechnology context than the pharmaceutical context where typically only one agency-for example, the FDA - has authority over new drug applications. ${ }^{284}$ While the ICH approach may be more complicated for biotechnology than pharmaceuticals, biotechnology has the advantage of being able to follow the example of ICH in creating a centralized organization and rulemaking procedure.

The biotechnology industry does have a centralized trade association; however, the industry does not have a comprehensive regulatory organization. ${ }^{285}$ The name of this trade association is Biotechnology Innovation Organization ("BIO"). ${ }^{286}$ It represents the interests of biotechnology companies, universities, and other biotechnology centers across the United States and in more than thirty other nations. ${ }^{287}$ However, $\mathrm{BIO}$ is missing the most critical piece of the regulatory puzzle: government. ${ }^{288}$ In order to remedy asynchronous approvals, the industry must look beyond their trade association representatives and instead seek to vest regulatory authority in an organization with governmental authority. Additionally, the centralized organization will benefit substantially from a welldeveloped relationship with WTO. Following this approach will mitigate the

277. $I d$.

278. Id.

279. Id.

280. Id.

281. See generallyid.

282. KALAITZANDONAKES ET AL., supra note 251.

283. Supra Part II.

284. See generally Mullin, supra note 273.

285. Biotechnology Industry Organization Changes Name to Biotechnology Innovation Organization, Bus. WiRE, (Jan. 4, 2016, 12:56 PM), https://www.businesswire.com/news/home/ 20160104006245/en/Biotechnology-Industry-Organization-Biotechnology-Innovation-Organization [https://perma.cc/QZ77-V93P].

286. Id.

287. $I d$.

288. Id. (noting that $\mathrm{BIO}$ does not represent governmental interests). 

THROUGH LITIGATION IN BIOTECHNOLOGY

disparate implementation of WTO standards for biotech regulations and promote compromise and uniformity in biotech regulations worldwide.

2. Amending the Cartagena Protocol.-If complete international harmonization cannot be achieved via the formation of a centralized regulatory organization, amending the Cartagena Protocol may still benefit the industry. The Cartagena Protocol on Biosafety was negotiated under the Convention on Biological Diversity and came into effect on September 11, 2003. ${ }^{289}$ The objective of the Protocol is to protect biological diversity from potential risks resulting from modern biotechnology. ${ }^{290}$ The Protocol attempts to regulate transboundary movements of biotech products by establishing rules and procedures for the international trade of GMO grain and derivative products. ${ }^{291}$ Unfortunately, the Cartagena Protocol is flawed, namely in its failure to reach global consensus on a standard approach to risk assessment. ${ }^{292}$ Additionally, the Protocol lacks an effective enforcement mechanism ${ }^{293}$ and tends to favor importers. ${ }^{294}$

There are two primary approaches to scientific risk assessment in biotechnology: (1) the precautionary principle and (2) the anti-precautionary principle. ${ }^{295}$ The European Union and several other importers of GMO grain follow the precautionary principle. ${ }^{296}$ The precautionary principle is a strategy used to cope with potential risks when scientific understanding is incomplete and potential exists for irreversible harm to human health or the environment. ${ }^{297}$ Essentially the precautionary approach denies product approval if there is potential that scientific understanding has yet to identify a conceivable harm from a given product. ${ }^{298}$ Further, the adoption of the precautionary principle is frequently accompanied by adoption of the zero tolerance principle for purity. ${ }^{299}$ For example, the European Union, which follows both the precautionary approach and zero tolerance principle, insists that every possible genetically engineered trait be identified within a grain shipment, and the European Union

289. Alan McHugan, Problems with the Cartagena Protocol, 10 AsiA-PACIFIC BioteCH NewS 684 (2006), http://www.asiabiotech.com/10/1012/0684_0687.pdf [https://perma.cc/UTS3-786E].

290. Id.

291. Cartagena Protocol on Biosafety, CROPLIFE INT'L, https://croplife.org/plantbiotechnology/cartagena-protocol-on-biosafety/ [https://perma.cc/588P-74T3].

292. See generally Alison Peck, The New Imperialism: Toward an Advocacy Strategy for GMO Accountability, 21 GeO. INT'L ENVTL. L. REV. 37, 48 (2008).

293. Katherine E. Kohm, Shortcomings of the Cartagena Protocol: Resolving the Liability Loophole at the International Level, 27 UCLA J. ENVTL. L. \& POL'y 145, 148-50 (2009).

294. See generally Redick, supra note 115, at 56-57.

295. Peck, supra note 292.

296. See generallyid.

297. See generally Precautionary Principle, Business DiCTIONARY, http://www. businessdictionary.com/definition/precautionary-principle.html [https://perma.cc/CR3P-ANHY].

298. See generallyid.

299. Redick, supra note 115 , at 57. 
will reject a shipment with even the slightest trace of unapproved genetic material. ${ }^{300}$ Conversely, the United States, the leading exporter of GMO grain, follows the anti-precautionary principle, which allows for product approval as long as the regulatory agencies' required scientific testing has revealed no threat of verifiable harm. ${ }^{301}$ Additionally, the United States rejects the zero tolerance principle and accepts low level presence of contaminants in bulk commodities. ${ }^{302}$

The Protocol states that risk assessments should be carried out in a scientifically sound and transparent manner and that a lack of scientific knowledge or consensus "should not necessarily be interpreted as indicating a particular level of risk, an absence of risk, or an acceptable risk." ${ }^{\prime 303}$ While the Protocol advocates for science-based risk assessment and effectively denounces the precautionary principle, many of the nations that have signed the Protocol follow the precautionary approach. ${ }^{304}$ Historically, the United States refuses to sign international agreements that endorse the precautionary principle. ${ }^{305}$ In sum, risk assessment under the Protocol has become an ideological sticking point between importers and exporters of biotech crops. ${ }^{306}$

Notably, signatories to the Protocol have failed to adopt a comprehensive liability regime for protocol infractions. ${ }^{307}$ With no ratified liability regime, disadvantaged parties must rely on international common law to redress harms under the Protocol. ${ }^{308}$ It is possible that a WTO sanction could be issued against nations violating the Protocol as a means to manipulate trade; ${ }^{309}$ however, sanctions may hurt other economic interests without changing the target nation's trade practices for the better. ${ }^{310}$ As explained above, China claimed to reject U.S. corn shipments on the basis of genetic contamination, yet China received shipments from Argentina containing the MIR162 trait. ${ }^{311}$ China is a signatory to the Protocol and the United States is not, ${ }^{312}$ but even if the United States had joined the Protocol, the Protocol would offer little redress for China's trade manipulation. ${ }^{313}$

300. Id. at 56-57.

301. See generally Peck, supra note 292.

302. Plant Biotechnology Regulatory, supra note 19.

303. The Cartagena Protocol Risk Assessment, Convention on Biological Diversity, https://bch.cbd.int/protocol/cpb_art15.shtml [https://perma.cc/AJ9Z-AURL].

304. Redick, supra note 115, at 59-65.

305. Peck, supra note 292, at 50-51.

306. See generally Peck, supra note 292, at 50-51; Redick, supra note 115, at 59-65.

307. Kohm, supra note 293, at 148.

308. Id. at 150 .

309. Westerman, supra note 59, at 775.

310. Richard N. Haass, Economic Sanctions: Too Much of a Bad Thing, Brookings, (June

1, 1998), https://www.brookings.edu/research/economic-sanctions-too-much-of-a-bad-thing/ [https://perma.cc/5XPB-DTJZ].

311. Supra notes 186, 187, and accompanying text.

312. The Cartagena Protocol on Biosafety, supra note 109.

313. See generally Kohm, supra note 293, at 148. 

THROUGH LITIGATION IN BIOTECHNOLOGY

Essentially, the current Cartagena Protocol is at an impasse between importers and exporters. ${ }^{314}$ To remedy this problem, the Protocol could be amended to state a more definitive approach to scientific risk assessment or to provide a more effective mechanism for remedying Protocol violations. Additionally, amending the Protocol to make the low-level presence of genetic contaminants acceptable would make the protocol more favorable for biotech exporters than currently structured and hopefully result in more signatories.

\section{CONCLUSION}

More than thirteen million farmers around the globe use agricultural biotechnology to increase yields, prevent damage from insects, and reduce farming's impact on the environment. ${ }^{315}$ Unfortunately, a fragmented regulatory regime poses challenges for companies trying to get their products into the hands of farmers who use them. ${ }^{316}$ In the United States, a new biotech product must undergo regulatory approval by three different agencies prior to commercialization, ${ }^{317}$ and abroad, every nation importing or exporting GMOs has authority to regulate biotechnology as it sees fit. ${ }^{318}$

Deficiencies in existing regulation often give rise to regulation through litigation, and as evidenced by the Syngenta litigation, biotechnology is no different. ${ }^{319}$ Unfortunately, regulation through litigation in the context of biotechnology has three notable shortcomings: the production of incomplete regulation, the inability to remedy asynchronous approvals, and competitive disadvantage for U.S. producers.

A lack of transparency and predictability is a challenge for biotech manufacturers trying to achieve regulatory approval in export markets. ${ }^{320}$ One solution to the problem of asynchronous approvals is the use of channeling. ${ }^{321}$ Unfortunately, bulk-commodity infrastructure often renders channeling efforts ineffective, especially in light of importers using the zero tolerance principle. ${ }^{322}$ Regulators around the globe need to harmonize approval processes to ensure

314. See generally Redick, supra note 115, at 59-65.

315. What is Biotechnology?, BIOTECHNOLOGY INNOVATION ORG., https://www.bio.org/whatbiotechnology [https://perma.cc/G5W7-NCS6].

316. See generally Fisk \& Bross, supra note 5.

317. Goeringer, supra note 46, at 377-78.

318. Global Approvals of GMO Crops, supra note 40.

319. Goeringer, supra note 46, at 380-83.

320. Dominique Patton, DuPont, Monsanto Urge Transparent GMO Crop Reviews in China, REUTERS, (July 17, 2017. 3:07 AM), https:/www.reuters.com/article/us-china-gmo/dupontmonsanto-urge-transparent-gmo-crop-reviews-in-china-idUSKBN1A20IC [https://perma.cc/HD3U8QMF].

321. Goeringer, supra note 46 , at 383.

322. Plant Biotechnology Regulatory, supra note 19. 
continued investment and innovation in biotechnology. ${ }^{323}$ This could be achieved by conferring regulatory authority in one centralized organization. Alternatively, strides should be made to amend the Cartagena Protocol.

Although class action litigation can provide immediate compensation for farmers affected by disrupted export markets, such litigation does not remedy the root cause of these disruptions to trade. Further, class action litigation in this context may disadvantage American farms in the long run by blocking access to new technologies and by disincentivizing future product development. Trade disruptions are a complex and multi-faceted problem, but the world cannot afford to let asynchronous approvals defeat innovation as farmers around the globe strive to feed us all.

323. Plant Biotechnology Product Launch Stewardship, supra note 90. 